\title{
Topology Design of Planar Structure Subjected to Mechanical and Thermal Loads
}

学 O速水 直希 (阪府大院)

正大多尾 義弘 (阪府大院)

Naoki HAYAMI, Graduate School of Enginnering, Osaka Prefecture University, 1-1, Gakuencho, Naka-ku, Sakai, Osaka Yoshihiro OOTAO, Graduate School of Enginnering, Osaka Prefecture University

\section{1 緒 言}

構造部材の形状決定は機械構造物の設計において重要な 課題である. なおかつ，近年は資源の有効活用も無視する ことのできない問題となっている. そのため, 構造部材は 必要な強度を保ち，かつ軽量である必要がある，効率的な 形状を求める形態設計法については古くから様々な研究が 行われているが，その方法の一つとして構造全体の応力を 均一にする方法がある.

応力均一化を目標とする構造設計方法として, CA 法 (Cellar Automaton) 等を用いた位相設計法が考えられてい る. 有限要素法により応力を求め, 応力が小さい部分を構 造物から削除することにより, 構造物全体の忘力が均一に なる形状を得る方法である．しかし，今までの報告例(1)(2) は力学的荷重のみを考慮した平面構造設計の研究であり, そこに熱負荷が加わった場合の研究はあまり行われていな い. そこで本研究では, 熱負荷の影響が平面構造設計に与 える影響を調べることを目的とし，CA 法を用いて局所的 なルールを設定し位相設計を行う。そして，得られた形状 および数値計算結果に対する考察を行う.

\section{2 位相設計}

\section{$2 \cdot 1$ 応力解析}

任意の初期領域を均一な正方形セルに分割したものを, 4 節点 8 自由度平面応力要素の有限要素モデルとする. 力学 的荷重と熱負荷の両方が作用しているので, まず有限要素 法により各節点の温度分布を求め, 式(1)により各節点にか かる熱荷重を求める.

$$
\left\{f_{t}\right\}=\frac{E \alpha T t}{2(1-v)}(\mathbf{x})
$$

ただし，Eはヤング率， $\alpha$ は線膨張係数，Tは各節点温度， $t$ は板厚, $v$ はポアソン比である. 式(1)を考虑することによ り, 各節点にかかる全荷重が得られ, 応力を求めることが できる. 応力の評価は式(2)で与える相当応力 $\sigma_{i}(\mathbf{x})$ を用いる. 下付き添字 $i$ は世代数を示す.

$\sigma_{i}(\mathbf{x})=\sqrt{\frac{1}{2}\left\{\left(\sigma_{i, x}(\mathbf{x})-\sigma_{i, y}(\mathbf{x})\right)^{2}+\sigma_{i, x}(\mathbf{x})^{2}+\sigma_{i, y}(\mathbf{x})^{2}+6 \tau_{i, x y}(\mathbf{x})^{2}\right\}}$

\section{$\mathbf{2 \cdot 2}$ 設計変数}

構造における材料の有無を次の密度関数 $\rho_{i}(\mathbf{x})$ を用いて 次式のように表現することにする.

$$
\rho_{i}(\mathbf{x})= \begin{cases}1.0 & \text { if } \quad \mathrm{x} \in \Omega_{s} \\ \rho_{L} & \text { if } \quad \mathrm{x} \in \Omega / \Omega_{s}\end{cases}
$$

ただし， $\Omega_{S}, \Omega / \Omega_{S}$ はそれぞれ材料のある領域，材料のない 領域を示す。なお，計算の都合上，生存セルの密度を 1.0 , 死滅セルの密度 $\rho_{L}$ を非常に小さな正の值とする. この密度 関数の変化によって，ヤング率，熱伝導率を式(4),(5)のよ うに更新する.

$$
E_{i}(\mathbf{x})=E_{0} \rho_{i}(\mathbf{x})
$$

$$
k_{i}(\mathbf{x})=k_{0} \rho_{i}(\mathbf{x})
$$

ただし， $E_{0}$ はヤング率の初期值， $k_{0}$ は熱伝導率の初期值で ある.

\section{3 更新則}

各セルの局所的な相当忍力の大きさ表す変化率 $R_{i}(\mathrm{x})$ を 設ける.

$$
R_{i}(\mathbf{x})=\frac{\sigma_{i}^{0}}{\operatorname{Ave} \sigma_{i}}
$$

ただし， $\sigma_{i}^{0}$ は当該セルの相当応力值である.ここで, Ave $\sigma_{i}$ は当該セル近傍の平均忘力である，上記の設計変数の更新 のためのルールを表 1 のように定める.

Table.1 Basic rule

\begin{tabular}{|c|c|c|}
\hline & $\sigma_{i}(\mathbf{x}) \leq \sigma_{i, \text { cut } 1}$ & $\sigma_{i}(\mathbf{x}) \geq \sigma_{i . c u u 2}$ \\
\hline$R_{i} \geq 1$ & Stay & Revive \\
\hline$R_{i} \leq 1$ & Delete & Stay \\
\hline
\end{tabular}

ただし， $\sigma_{i, \text { cut } 1} ， \sigma_{i, \text { at } 2}$ はそれぞれ削除ルール・復活ルール の闇值である.

当該セルが表 1 の Delete を満たすときセルの削除を行う. また，当該セルが表 1 の Revive を満たすとき，当該セルの 近傍セルを生存セルとする. 当該セルが Stay の状態の場合 はセルの更新を行わない。

\section{4 数值計算例}

図 1の $L=90[\mathrm{~mm}], H=210[\mathrm{~mm}] の$ 片持ちはりに対し, 荷重 $P=100[\mathrm{~N}] か ゙$ 作用する場合を考える. 板厚 $t=1.0[\mathrm{~mm}]$, セル分割数を $18 \times 42$, ポアソン比 $v=0.28$, 線膨張係数 $\alpha=11.5 \times 10^{-6}[1 / \mathrm{K}]$, 初期状態のヤング率 $E_{0}=207[\mathrm{GPa}$, 熱 伝導率 $k_{0}=52[\mathrm{~W} /(\mathrm{m} \cdot \mathrm{K})]$ とする. また, 式(3)の $\rho_{L}$ を $1.0 \times 10^{-3}$ とする. 一例として上記の荷重に加え, 温度上昇值 $T=10\left[{ }^{\circ} \mathrm{C}\right]$ の場合での最も応力の均一性が高い形状を図 2 に示す.

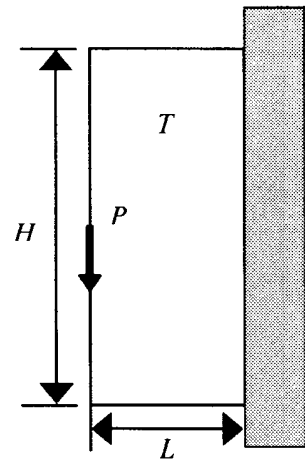

Fig.1 Design domain

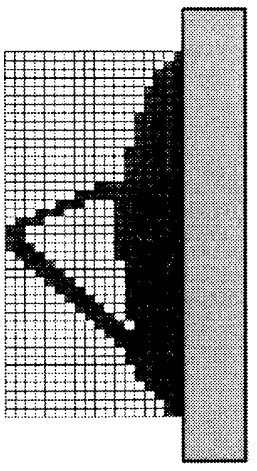

Fig.2 Optimum construction 参考文献

[1] 牧野·大多尾・谷川, 機構論, No.054-1(2005)5.3-4

[2] 石田·大多尾・谷川, 機構論, No.06-4(2006)541-542 